\title{
Skills and low pay: upgrading or overeducation?
}

Citation for published version (APA):

Borghans, L., \& de Grip, A. (1999). Skills and low pay: upgrading or overeducation? Researchcentrum voor Onderwijs en Arbeidsmarkt, Faculteit der Economische Wetenschappen. ROA Research Memoranda No. 5E https://doi.org/10.26481/umaror.199905E

Document status and date:

Published: 01/01/1999

DOI:

10.26481/umaror.199905E

Document Version:

Publisher's PDF, also known as Version of record

\section{Please check the document version of this publication:}

- A submitted manuscript is the version of the article upon submission and before peer-review. There can be important differences between the submitted version and the official published version of record.

People interested in the research are advised to contact the author for the final version of the publication, or visit the DOI to the publisher's website.

- The final author version and the galley proof are versions of the publication after peer review.

- The final published version features the final layout of the paper including the volume, issue and page numbers.

Link to publication

\footnotetext{
General rights rights.

- You may freely distribute the URL identifying the publication in the public portal. please follow below link for the End User Agreement:

www.umlib.nl/taverne-license

Take down policy

If you believe that this document breaches copyright please contact us at:

repository@maastrichtuniversity.nl

providing details and we will investigate your claim.
}

Copyright and moral rights for the publications made accessible in the public portal are retained by the authors and/or other copyright owners and it is a condition of accessing publications that users recognise and abide by the legal requirements associated with these

- Users may download and print one copy of any publication from the public portal for the purpose of private study or research.

- You may not further distribute the material or use it for any profit-making activity or commercial gain

If the publication is distributed under the terms of Article $25 \mathrm{fa}$ of the Dutch Copyright Act, indicated by the "Taverne" license above, 


\section{Skills and low pay: upgrading or overeducation?}

ROA-RM-1999/5E

Lex Borghans en Andries de Grip

The authors like to thank Peter Sloane who provided us an extensive overview of studies on underutilisation, which has been used in section 3 .

\section{Research Centre for Education and the Labour Market}

Faculty of Economics and Business Administration Maastricht University

Maastricht, December 1999 
ISBN 90-5321-281-7

SEC99.179/LB 


\section{Contents}

1 Introduction

2 What is the right level of education for a job?

3 How should underutilisation be measured?

4 Shifting allocation of skilled labour: Causes and consequences

4.1 Increasing supply or decreasing demand for higher educated

4.2 Upgrading

4.3 Heterogeneity of labour within an educational category

4.4 Screening

4.5 Efficiency wages and search equilibria 



\section{Introduction}

In most industrialised countries, one may observe the tendency for higher educated people to be employed in jobs that used to be occupied by lower skilled people. Although this tendency appears to be a rather general phenomenon, economic literature provides no clear clue about the causes of this stylized fact. Explanations vary from the pessimistic view in which the value of diploma's decreases over time and further investments in education are wasted money, to the view that knowledge becomes the crucial production factor, which is required in more and more occupations.

One of the first studies that has put forward the pessimistic view has been Freeman's (1976) Overeducated American. Freeman suggested that students invest too much in their education. Based on dated information about the labour market, students expected good labour market prospects after graduation. In reality however the increasing supply of higher educated people could not be absorbed by the market and many school leavers were forced to accept a job that required less skills than they actually obtained. The trend that school leavers find jobs that were occupied before by people with lower qualifications, is therefore often associated with ( $I$ ) overinvestment in education, (ii) a wastage of knowledge, (iii) a decrease in pay for skilled labour. Furthermore, (iv) these underutilised workers who occupy jobs below their educational background take away appropriate jobs for lower skilled workers. This is thought to lead to a bumping down process on the labour market, $(v)$ ultimately pushing low-skilled workers into low pay jobs or crowding out the low-skilled from the working population.

In contrast with this rather negative picture about the role of education in the recent decades, there is a clear tendency in both the policy and academic debate to stress more and more the importance of knowledge in our society. This discussion perhaps with Leontief (1953) who suggested that not the physical capital endowment of the USA, but rather its endowments in terms of skills, explained the paradoxical trade patterns of the United States. Recently the European Commission (1996) claims that education and training should get a priority with regard to European competitiveness. The Commission therefore suggests to 'treat material investment and investment in training on an equal basis'. In line with this OECD (1996) states that 'OECD governments are strongly committed to improving the skills of their citizens as one of the principal means for dealing with current economic uncertainty'. Similar to technological progress, productivity growth might be obtained by an input of more skills in the production process i.e. an upgrading of the skill level of the labour force. Human capital will become the decisive factor in international competitiveness (Porter, 1990). Recent economic literature in particular focuses on the causes of this upgrading process in the so-called 'technology versus trade' debate (e.g. Wood, 1994 and Machin, Ryan and Van Reenen, 1998). ${ }^{1}$

1 This 'technology versus trade' debate also focusses on the explanation of the shifts in demand towards the high skilled. The debate, however, particularly deals with the question to what extent this shift can be explained by changes in the industrial structure of the economy, while the 'upgrading versus overeducation' debate focuses on the explanation of the changed allocation of skills within a given occupation. 
The question whether the overeducation or upgrading argument holds is related to the literature on the development of the skilled-to-unskilled wage gap (e.g. Davis and Reeve, 1997, Johnson, 1997 and Topel, 1997). The upgrading of the required skills is often mentioned as a major cause of the increase in the earnings differential between high and low skilled workers (e.g. Bound and Johnson, 1992 and Katz and Murphy, 1992), whereas others explain the increase in wage inequality in countries as Sweden and the Netherlands by an overeducation of the workforce (e.g. Muysken and Ter Weel, 2000). On a perfect market this link between demand for educated labour and wages of course holds, but as will be shown in this paper, in case of market failures an overeducated workforce does not necessarily lead to a narrowing of the earnings differential between high and low skilled workers, as low wages for high skilled workers who are overeducated for their job might go together with high wages for those who are employed at their own level of education. Furthermore, formal qualifications might not represent a constant mix and level of skills over time. Screening theory (e.g. Lang, 1994 and Weiss, 1995) suggests that increased enrolment might lower the average abilities of school leavers, while Grogger and Eide (1994) explain part of the rise in the college premium by increased skills among graduates.

Although very different in character and policy implications, the overeducation and upgrading views about the role of skills in our society share some important empirical evidence about the relationship of education and the labour market. In the first place both views are consistent with the tendency for higher educated people to hold jobs that used to be occupied by lower skilled people. From the overeducation perspective this illustrates the underutilisation of skills, while from the upgrading perspective this illustrates that occupations require more skills nowadays. In the second place both views share a pessimistic perspective for low skilled workers. From the overeducation point of view, low skilled workers will be pushed into the least favourite jobs, or will even be crowded out from the working population, irrespective of their real abilities or potential productivity, whereas the upgrading view predicts that the role of low skilled workers will become more and more marginalised, because their skill-level does not meet the minimum requirements in the labour market any more.

Knowledge about the allocation of workers over occupations will therefore not directly provide an answer to the questions on the role of skills on the labour market. To grasp the significance of education and training for both economic development, and the position of the weakest groups - the low skilled workers - on the labour market, a better understanding is needed about the skills people have and the way they utilise these skills in their work. Unfortunately, much less is known about how workers' productivity is related to the way in which people use their skills, than we know about the allocation of the workers on the labour market. Due to the difficulty to measure skills, the evidence available remains limited to on the one hand detailed case studies, and on the other hand rough and limited indicators about skills which are representative for the labour market as a whole.

The opposing consequences of the upgrading and the overeducation views on the effectiveness of more investments in education and training, indicate that it is highly important for policy purposes to better understand the way in which an increase in the human capital investments of low-skilled workers is absorbed in the labour market. In economic literature the question 
whether additional investments in education and training are needed because of the upgrading processes in different occupations or only lead to overeducation of the work force, is easily associated with a debate about the way the labour market functions. Upgrading is associated with neo-classical theory in which additional skills are automatically rewarded by the market. Overeducation is associated with market failure, in which wages are rigid and allocation is far from efficient.

In this paper we will show however that the question about the macro efficiency of more investments in education and training is not in the first place related to the efficiency of the market. The effects of educational investments depend on specific characteristics of the segment of the labour market concerned, such as the elasticity of demand for each occupation and the substitutability between different skill levels within each occupation. We will show that even in a perfectly functioning market low elasticities of demand might lead to a bumping down process, while on the other hand, limited substitutability between skill levels might urge the need for an upgrading of the skill level of the labour force. Only in addition to this, market failures might further complicate things.

Many advocates of a skill based policy to combat the alleged increase in international competitiveness in a 'knowledge intensive economy' still regard it as a role for the government to stimulate the acquisition of skills. This illustrates that even proponents of the upgrading view assume market failures to hamper the functioning of the market and thus do not take market perfection as given. Where in theory two different kinds of explanations for the shift of higher educated people towards low-level jobs compete, in practice this shift in the allocation of labour might be the joint effect of both processes which are simultaneously changing the labour market.

For an effective policy it is crucial to gain insight in the conditions that determine the macro efficiency of education and training investments. The aim of this paper is therefore to discuss the effects of changes in supply and demand on the utilisation of skills, and the way in which shifts in the skill structure of the workers in various occupational groups affect the effectiveness of education and training policy. For this purpose we first go further into the question what determines the optical level of education for a job and the different ways the underutilization is measured in economic literature. Furthermore, we will develop a typology of economic theories on the possible causes and consequences of the observed changes in the allocation of skilled labour and the related policy implications with respect to the (macro) efficiency of training policies for low skilled people.

The remainder of the paper is organized as follows. Section 2 starts with a theoretical investigation about what is meant by the skill level of a job. By comparing the 'occupational productivity profile' with the 'education-wage profile' it will be shown that the optimal skill level in a particular occupation has to be viewed as an interaction between on the one hand potential productivity in that occupation, and on the other hand supply and demand developments in the labour market. Next, the measurement of underutilisation of skills will be discussed in section 3. In economic research three different approaches to measure underutilisation can be distinguished. In the light of the investigation of the optimal skill level, these concepts are 
discussed, and empirical examples are provided. In section 4 an overview is given of possible causes of shifts in the educational structure of occupations. In this section different theories will be presented that explain this observed tendency of a movement within jobs towards the employment of higher educated. Moreover the consequences for both the higher and lower skilled workers will be discussed. The section will be concluded by a typology of the theories discussed. Finally, section 5 concludes with a discussion of the implications of the various theoretical points of view for the macro efficiency of training policies for low skilled and low paid workers.

\section{What is the right level of education for a job?}

In everyday language it is common to state that a certain occupation requires a certain level of education. In such a simple picture of the relationship between education and work it is implicitly assumed that jobs of a certain level can not be performed by a worker with lower qualifications: the productivity of the latter is zero. On the other hand people with higher qualifications than required for the jobs they have are thought to fully waste their abundant qualifications: their productivity in a job below their educational level equals the productivity of workers with an adequate educational background for this kind of job.

Many empirical studies, however, question this rigid interpretation and suggest a more gradual relationship between productivity and educational background. Hartog and Jonker (1998) provide an overview of many empirical studies which show a gradual, but non-linear relationship between education of workers and productivity. ${ }^{2}$ This is illustrated by table 1 which gives the wage effects of the (mis)match between the job level and the level of education of workers. The table shows that the productivity of a worker with a certain level of education increases with the level of the occupation. At the same time the table shows - following the diagonals - that in most cases the productivity of higher educated people in lower level jobs exceeds the productivity of the lower educated at the same job level. An exception are the academics working below their skill level compared to people with an educational background in higher vocational education, working in a job that matches their skill level. The earnings of academics are below the earnings of the workers with higher vocational education in these jobs.

2 All empirical results which demonstrate this gradual non-linear relationship between education and productivity are based on the assumption that wages reflect productivity. The neo-classical law that productivity equals wages assumes however an optimal allocation of workers over the jobs. Since these analyses try to catch the consequences on productivity when allocation is changed, and therefore compare people with the same qualifications in jobs at different levels, this assumption is violated. Although very illustrative for the idea that productivity depends on allocation, the estimates are in fact based on an inconsistency. Neo-classical theory would state that either workers with the same educational background are indifferent between jobs at different levels, e.g. because the wages are equal in each job, or that there must be differences in skills between these people with a formally equal qualification. More insight is therefore needed about the way in which skills differences influence allocation and productivity. 
Table 1

The effect of allocation on log net hourly wage from Hartog (1985). Job level, relative to 'adequate match' by educational level (t-values between brackets)
lower extended lower
Level of education
intermediary higher vocational university

$\begin{array}{lccccc}\text { Relative job level } & & & & & \\ \text { Below } & - & 0.063 & 0.288 & 0.508 & 0.536 \\ & & (1.68) & (7.80) & (11.05) & (11.04) \\ \text { Equal } & - & 0.170 & 0.440 & 0.607 & 0.860 \\ & & (6.04) & (10.49) & (15.77) & (14.19) \\ \text { Above } & 0.115 & 0.330 & 0.478 & 0.829 & - \\ & (2.65) & (8.30) & (10.35) & (10.52) & \end{array}$

Hartog tests whether the influences of education and occupational level are additive. This hypothesis is rejected, suggesting the existence of comparative advantages. In general the extra earnings for a job above ones educational level are less than the lost earnings in jobs below ones educational level.

\section{Occupational productivity profiles and the education-wage profile}

In the so-called assignment or matching theory introduced by Roy $(1950,1951)$ and Tinbergen $(1956,1975)$ within each occupation productivity is assumed to depend on the level of skills. Therefore, the relationship between productivity and skill level - the occupational productivity profile - will vary between different jobs. On a perfect labour market, in contrast with this, the relationship between wage and skill level - the education-wage profile - is equal for the whole labour market, and might vary with the labour market developments.

Figure 1 illustrates these relationships for a specific occupation. Such occupational productivity profiles have been introduced by Knight (1979). In this example the education-wage profile increases gradually with the level of education, while productivity rises sharply around 15-18 years of schooling. For lower qualification levels productivity remains low and does not catch up with the wage increase, while also for higher qualifications the additional productivity of one additional year of schooling will not compensate the increase in wage costs. The ratio between productivity and wage costs shows that for employers, workers with 19 years of schooling provide the optimal combination of productivity and wages. This implies that even the 19th year of schooling, which increases productivity only to a limited extent, still contributes more to productivity than it costs.

Figure 1 also shows that although the productivity-wage-ratio reaches its maximum at 19 years of schooling, the ratio has only modestly lower values in the 18-20 years of schooling interval. This might imply that employers are approximately indifferent between people with educational backgrounds within this interval. 
Figure 1

An occupational productivity profile, and an education-wage profile, determining together the optimal skill level for a specific occupation

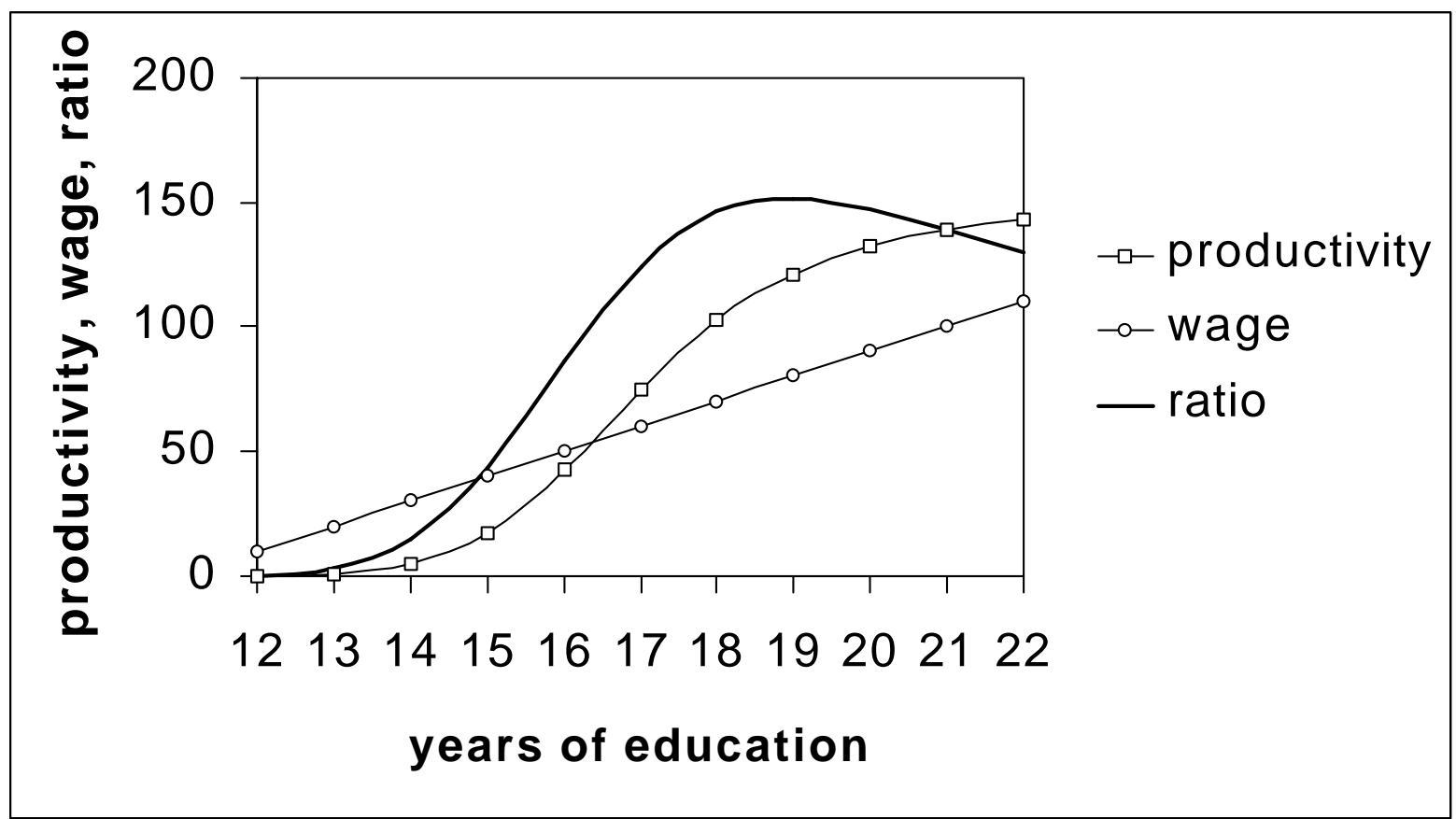

This is illustrated by the way the US Bureau of Labor Statistics indicates the educational requirements for a particular occupation in terms of 'at least this level, but some/many employers prefer...' (BLS, 1985). Although the education-wage profile has been introduced in the figures 1 and 2 as exogenous, in neo-classical theory it has to be regarded upon as the outcome of an equilibrium process. On each occupational market, demand in terms of units of production will depend on the production costs. Given the wage structure on the total labour market, it is possible to determine the required educational level per occupation and the demand in number of persons. Therefore the aggregate demand per educational level can be determined. If supply is assumed to be constant, i.e. the decision whether or not to participate on the labour market does not depend on the wage level, this aggregate demand for a particular educational level might differ from total supply at that educational level.

Figure 2 shows a job which is characterized by an occupational productivity profile with a gradual increase in productivity if the level of education is higher people with a different educational level are employed.

This increase is proportional with the increase of the education-wage profile. As a consequence, employers will be almost indifferent about the amount of human capital an employee brings in within the range of 15 to 22 years of education. Empirical research shows that there are indeed occupations in which people with a different educational level are employed. 


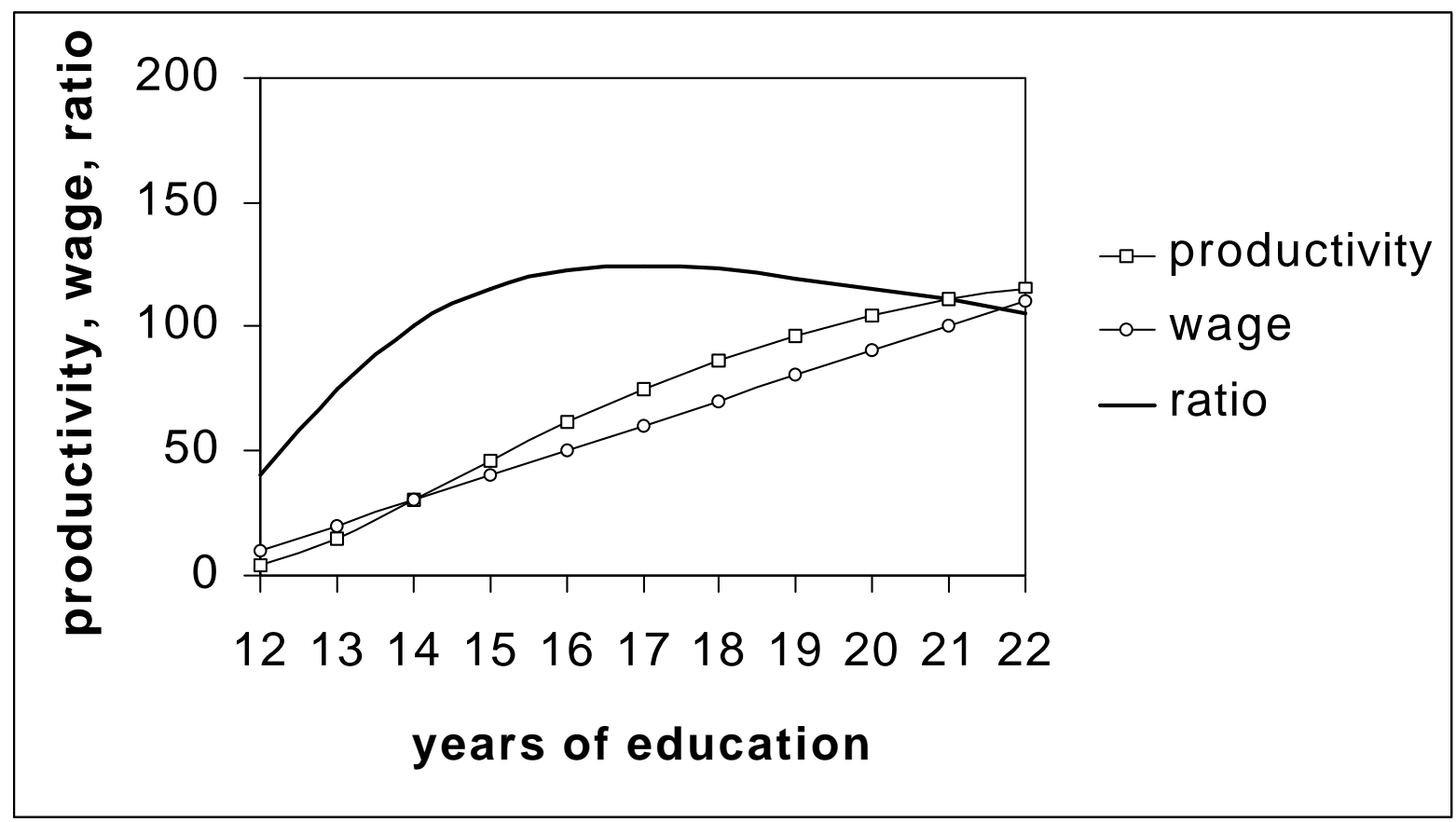

Borghans, De Grip and Smits (1997) show that while occupations like the lower printing industry occupations and the lower chemical industry occupations are matched exclusively to one educational level (Intermediate Vocational Education), other occupations like lower technical and industrial occupations and lower transport occupations seem to allow for a wide variety of educational levels.

It is important to notice that although employers are indifferent between employers with an educational background within this interval, productivity will not be equal for all workers in this group. Higher educated workers are more productive, but also have higher wage costs.

This increase is proportional with the increase of the education-wage profile. As a consequence, employers will be almost indifferent about the amount of human capital an employee brings in within the range of 15 to 22 years of education. Empirical research shows that there are indeed occupations in which people with a different educational level are employed.

Borghans, De Grip and Smits (1997) show that while occupations like the lower printing industry occupations and the lower chemical industry occupations are matched exclusively to one educational level (intermediate Vocational Education), other occupations like lower technical and industrial occupations and lower transport occupations seem to allow for a wide variety of educational levels.

It is important to notice that although employers are indifferent between employers with an educational background within this interval, productivity will not be equal for all workers in this 
group. Higher educated workers are more productive, but also have higher wage costs.

Within the indifference interval productivity increases proportionally to the wage increase however. Allocation theory suggests that higher educated handle the work differently, or perhaps carry out the more complicated tasks and therefore will be more productive than their college's with lower qualifications.

Educational levels with excess supply will face falling wages, while educational levels for which demand exceeds supply show wage increases. An adjustment process of the wages will ultimately lead to an equilibrium of supply and demand for each educational level. Teulings (1995) estimates such a model in which wages and allocation are investigated simultaneously. The education-wage profile that results in this equilibrium, indicates the returns to education. For each additional year of schooling it provides the additional wage an employee can expect. If students anticipate these returns adequately, their educational investment decisions will adjust to these returns to education. If certain levels of schooling have low returns less students will invest in this level of education. As a consequence returns will go up again. Assuming a perfect market for education in which students perfectly foresee the returns on their human capital investments, the capital market is not restricted and the only benefits from education are the returns in the form of future wages, the education-wage profile will become approximately linear with a slope that depends on the discount rate. ${ }^{3}$ However, in order to analyse the causes of a changing match between education and jobs, it is not relevant whether the educational investments are in equilibrium. The only aspect that matters is that given the supply of educated labour, wages reflect the scarcity of educated labour.

\section{Shifts in the education-wage profile and the occupational production profiles}

Allocation theory provides an explanation for what is meant by the statement that for a certain occupation a specific educational level is required. This refers to the match which is optimal given production possibilities and given the supply of labour. However, also within this theoretical framework, the required level is not fixed, but might change. On the one hand such changes can result from shifts in the education-wage profile. These shifts can be the results of changes in the demand for certain occupations (in units of production) or the supply of labour at certain educational levels. On the other hand changes in the optimal level of education in an occupation can result from changes in the occupational production profile due to technological or organizational developments.

The change in the optimal skill level in a certain occupation due to a shift in the education-wage profile is illustrated in figure 3 . Compared to figure 1 the optimal level of education increases

3 Since more education will also shorten the period in which returns are obtained, the slope will raise with the years of schooling slightly. Furthermore, Borghans (1993) discusses the effects on educational decisions of imperfect information about the returns, Kodde (1986) analyses the impact of constraints on the capital market and Oosterbeek and Webbink (1995) discuss the impact on educational decisions from a consumption effect of education. 
from 19 towards 20 years of education. Figure 4 shows the effect of a change in the occupational productivity profile on the optimal skill level. Compared to figure 1 the optimal level of education in this occupation again increases from 19 towards 20 years of education.

Both the change in the supply of educated labour, which results in lower wages for higher educated as shown in figure 3 and the change in the occupational productivity profile as shown in figure 4 result in a situation in which the people that are employed in this occupation have an educational background which is higher than it used to be. Such a shift might easily be associated with overeducation or underutilisation.

However, only in figure 3 - by flattening the education-wage profile - excess supply of higher skilled people has increased the optimal level of education in the occupation concerned. The figure therefore illustrates the overeducation view.

Figure 3

A shift in the optimal skill level of an occupation due to a shift in the education-wage profile, caused by changes in demand or supply

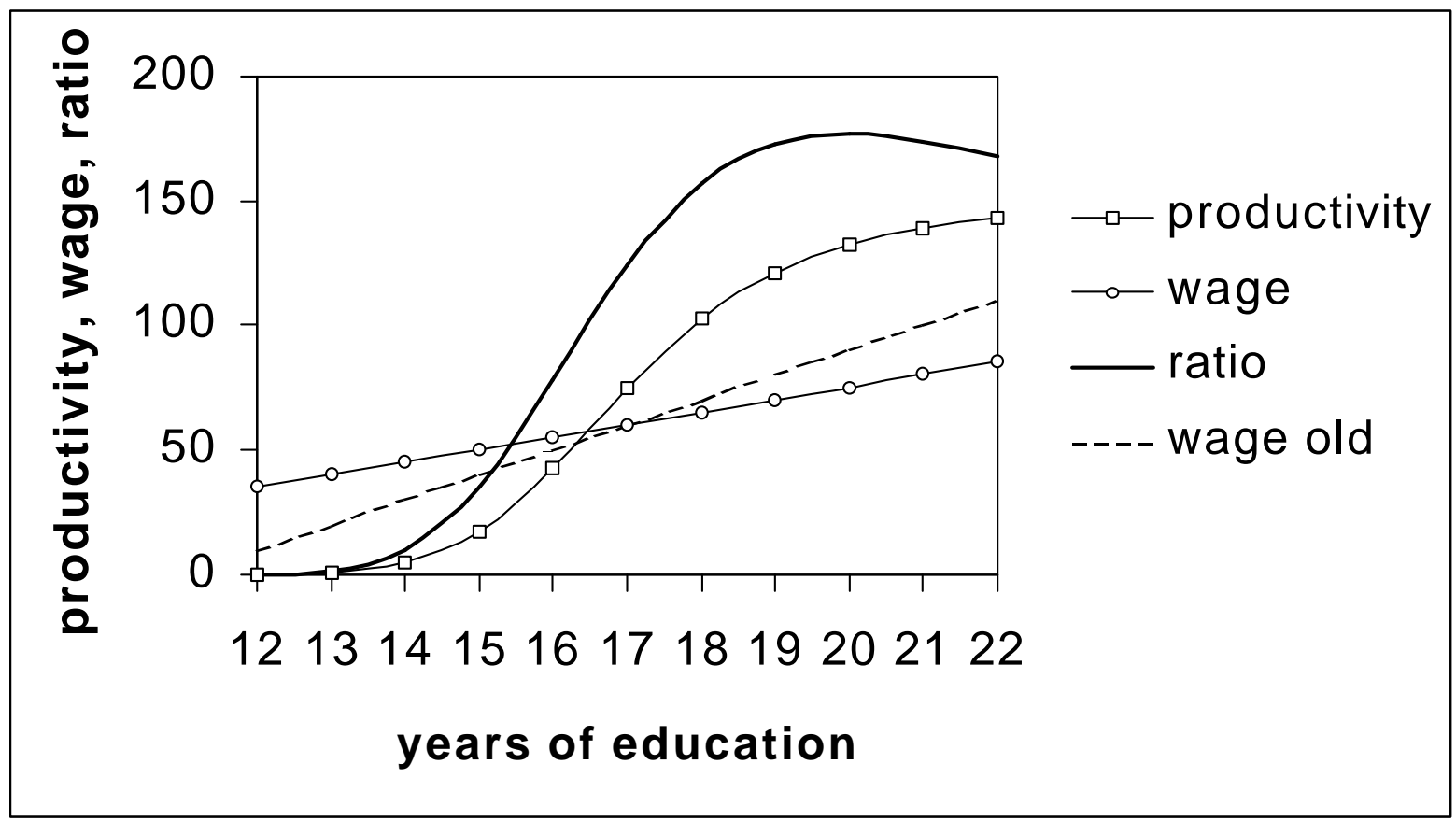

However, the figure also shows that this does not mean that the higher educated workers employed in this occupation do not utilise their extra skills, since their productivity in this occupation is higher than the productivity of the workers with less years of education and furthermore - give the labour market conditions - it is for them not possible to reach a higher level of productivity. 
Figure 4

A shift in the optimal skill level of an occupation due to a change in the occupational productivity profile, caused by the introduction of new technology

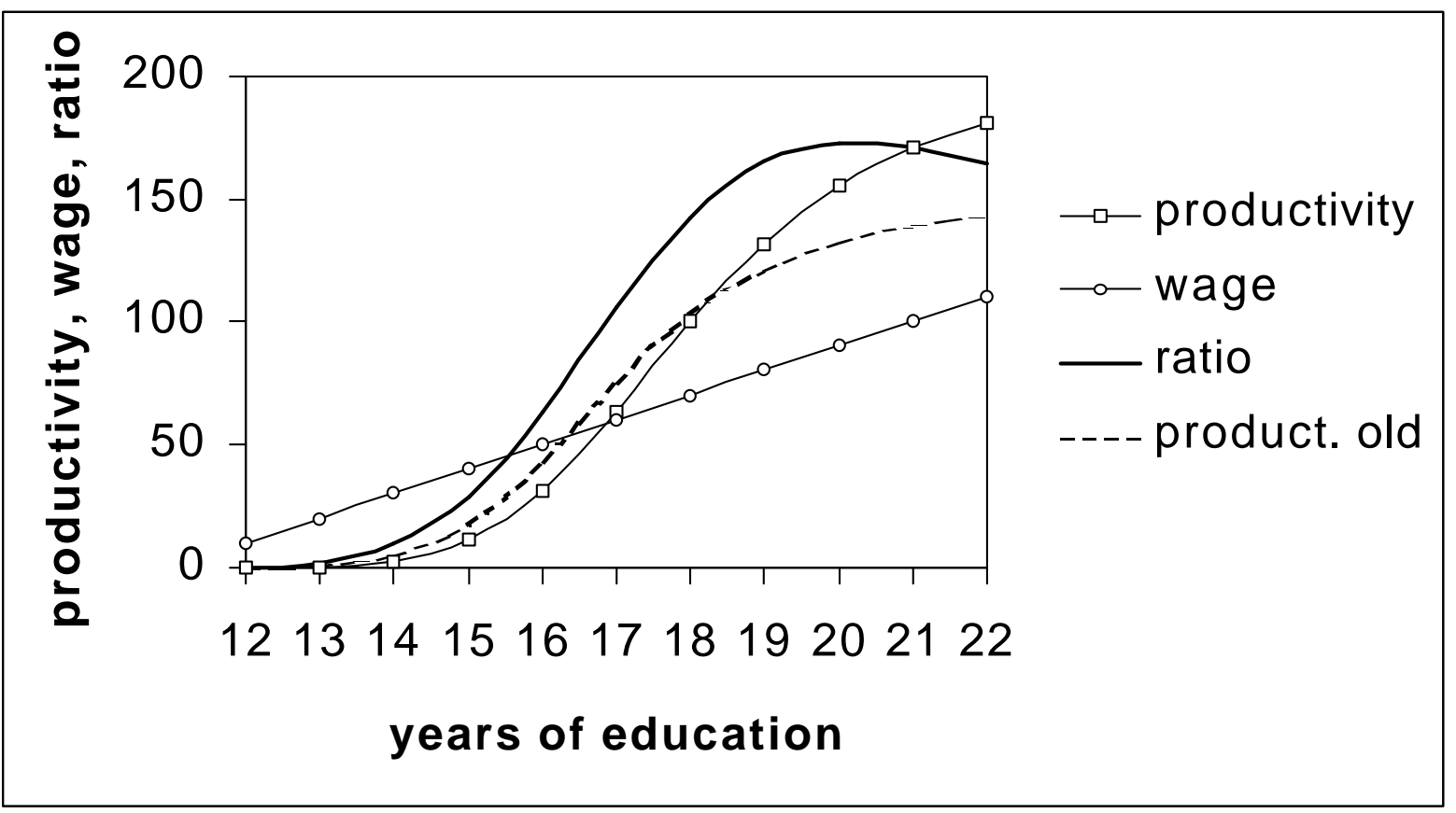

Figure 4 illustrates the upgrading view. Here the change in the production process due to e.g. technological or organizational developments increases the demand for higher educated workers. This means that higher educated people will be occupied in this occupation that used to be the domain of people with lower levels of qualifications. The productivity of these higher educated will, however, not be lower than the productivity they have - and used to have - in their traditional occupational domain. New technologies have, as a matter of fact, opened possibilities to utilise the skills these people have also productively in these new jobs. Therefore there is no underutilisation of their level of qualification.

Thus, allocation theory is able to explain the tendency that higher educated people occupy jobs that used to be occupied by lower educated both from a supply and a demand side perspective. Within this neo-classical framework, skills are always utilised optimally, given the actual labour market conditions. In fact three grades of underutilisation of skills can be distinguished:

C First, someone might be employed in a job were people with the same educational background used to have a lower productivity than in their original occupational domain, but where now productivity is at least equal to the productivity in this original domain. This is the case in an upgrading process, where actually one can only speak of alleged underutilisation of skills.

C Second, someone might be employed in a job where he or she has a lower productivity than people with the same educational background used to have, but which equals the productivity 
these people have nowadays. This is the case in a situation of excess supply on a perfect labour market and might be called intertemporal underutilisation of skills.

Overeducation is however generally associated with underutilisation of skills on a labour market which is far from perfect and where a part of the work force with a certain skill level is occupied in jobs where they are less productive than others, therefore,

C Third, workers might be employed in a job where they have a lower productivity than other people with the same educational background currently have. This genuine underutilisation of skills is not explained by allocation theory.

\section{How should underutilisation be measured?}

As both the overeducation ('bumping down') and upgrading views are consistent with the stylized fact that higher educated people obtain jobs which were previously hold by lower skilled workers it is difficult to distinguish between both views in empirical research. This problem is enlarged by the fact that - despite the large number of empirical studies in this field - the measurement of underutilisation of skills is far from straightforward. The problem is not helped by the fact that various terms are used to describe essentially similar situations (Shockey 1989). Thus skill underutilisation, overeducation, overqualification, underemployment, overtraining and occupational mismatch are often used interchangeably.

Underutilisation is most simply defined as a level of educational attainment greater than the educational requirement of the occupation in which someone is employed. ${ }^{4}$ The previous section has shown however that it makes no sense to speak about a 'required level' for a certain occupation as such. The optimal allocation of skills over occupations will vary with changes in supply and demand for the occupation concerned, but also with changes in the optical allocation in other occupations. Harvey, Moon and Geall (1997) e.g. suggest that the distinction between graduate and non-graduate jobs is artificial because graduates alter the nature of a job. Further, technological change and shifts in demand may also alter the relative demand for certain skill levels in particular occupations. Other authors have argued that employers hire educated workers for jobs with lower educational requirements, precisely because they are more productive and reduce the cost of training (see, for instance, Sicherman 1991). This recognizes the fact that education is only one form of human capital and one which can be substituted for on-the-job training to the extent that more educated workers will take a shorter period of time to become fully proficient at the job.

In a study of Mason (1997) on engineering supervisors in the US and the UK it was found that only $20 \%$ of production supervisors in British plants were graduates compared to $35 \%$ in the US.

4 Exceptions are the study of Sloane, Battu and Seamon (1995) and Borghans and Smits (1997) who distinguish different levels of underutilisation. 
However, British managers recognized several advantages in employing graduate engineers alongside traditional supervisors trained on the shop floor. For example, graduates were better at utilising computer systems and keeping up to date with technological developments. They played a key role in planning and implementing new cellular work systems, and finally they had the ability to combine the previously separate roles of manufacturing manager (usually office rather than shop-floor based) and production supervisor. This kind of evidence therefore again suggests that higher educated workers might perform differently in an occupation and thus leaves open the question whether this can be viewed upon as underutilisation.

Many empirical studies suggest however that there is a substantial proportion of workers that does not fully utilise their skills. Their claim is that part of the workers with a certain educational background, are employed in jobs for which less skills would have been sufficient. Their productivity is therefore lower than the productivity of equally skilled workers in adequate jobs. This is what we call underutilisation of skills. Underutilisation of skills means that at least part of the potential productivity of the labour force is not utilised. In that sense it can be compared with unemployment. ILO (1996) therefore speaks about 'underemployment' in a situation where similar people have more productive jobs. Underutilisation is treated here on equal basis with part-time unemployment.

To support the claim about the underutilisation of skills, measurement is needed. However, direct measurement of the way in which people organize their work and thereby utilise their skills is rare. An interesting example of such research is provided by Stasz (1998). Based on very extensive observations of people at work, she draws conclusions about the role of competences such as problem solving, communications, and team work at the work place. Also Lam (1996) and Mason, Van Ark and Wagner (1994) provide interesting detailed studies about the utilisation of skills. Studies like these require large resources, however, and therefore can never provide a complete picture of the developments in skill utilisation on the labour market. To obtain such a more general view on the developments in skill utilisation in practice indirect methods are needed.

There are three main alternatives in the measurement of underutilisation. First there is the socalled objective measure depending on systematic evaluation by professional job analysts who attempt to specify the required level and type of education in particular occupations. The best known data set used in a number of overeducation studies is the Dictionary of Occupational titles (DOT) established by the US Employment Service. In this approach the same job is first analysed in two different establishments in one State and then in two different establishments in another State. Six components of worker traits are assessed - training time, aptitudes, interests, temperaments, physical demands and working conditions (see Rumberger, 1981). The Department of Labor's (1972) Handbook for Analysing Jobs, shows that the training time requirements are derived from two questions. The first asks what level of general educational development is necessary for a worker to obtain the necessary background knowledge to perform the work in question. The second asks how long in terms of specific vocational preparation it takes for a worker with a specified level of educational development to become a fully qualified worker on the job in contrast to a trainee. European equivalents to DOT are few 
and far between. One exception is the ARBI-code which involves a classification into seven levels of job complexity and has been developed by the Dutch Department of Social Affairs (see Hartog and Oosterbeek, 1988). The classification takes into account both the job content and the employee's ability and knowledge in attaining the required level of proficiency. The scale ranges from very simple work with a training time of a few days (level one) to work on a scientific basis at level seven.

The second approach is based on worker self assessment and can therefore be referred to as a subjective assessment. Examples include the Michigan Panel Study of Income Dynamics question which asks 'how much formal education is required to get a job like yours' or the British Social Change and Economic Life Initiative data set question which asks 'if they were applying today, what qualifications if any would some-one need to get the type of job you have now?' Related to these two different questions Green et al. (2000) distinguish 'credentialism' from 'underutilisation of skills'. Creclentialism means that an employer requires a certain skills level although these skills are not utilised. Workers with appropriate qualifications are just not recruited. A slightly different variant is the Spanish Living and Working Conditions Survey of 1985 (ECVT) which has been analysed by Alba Ramirez (1993). This includes two separate questions. The first asks 'considering the job you do how long would it take some-one with the required education, who begins the job to do it correctly?' Such periods of time may be interpreted as on-the-job, training requirements, but may be influenced not only by the complexity of the job, but also by the ability of the individual. The second question in the ECVT survey, asks 'what kind of education does a person need in order to perform the job?' This recognizes the possibility that there may be a distinction between the actual requirements of the job and the customary hiring requirement. This is consistent with the screening hypothesis which suggests that the labour market is characterized by imperfect information and education is used as a signal to identify to employers the more able, ambitious or productive workers. Finally some data sets may allow for the fact that there is no unique educational requirement. Thus, the $1980 \mathrm{UK}$ National Survey of Graduates and Diplomates asks 'what was the minimum formal qualifications required for (entering) this job?' (See Dolton and Vignoles, 1997). As Hartog (1997) notes the above definitions are clearly different from one another, but they may not necessarily be perceived as so by the respondents.

The third approach focuses on the distribution of educational qualifications in a given occupation. Most commonly underutilisation is defined as a level of education more than one standard deviation above the mean and under-education as a level of education more than one standard deviation below the mean (see, for instance, Verdugo and Verdugo 1989). This so-called empirical method clearly differs from the above measures in defining underutilisation as being substantially underutilised. It also implies symmetry and will clearly give biased estimates where the tendency to underutilisation or overutilisation is skewed. In almost all studies the percentage of workers whose skill level is underutilised exceeds the percentage of workers who are overutilised. Therefore it seems more appropriate to consider the underutilisation of skills in relation to the mode rather than the mean, as Santos, Oliveira and Kiker (1996) do for Spain and Alpin, Schackleton and Walsh (1997) do for Britain. Borghans, et al. (1997) formulate criteria which enable to identify a range of skill levels as appropriate on an empirical basis. 
It is clear that the above approaches to the measurement of underutilisation of skills can lead to divergent estimates. All three approaches have been criticized on various grounds. As Hartog (1997) notes, conceptually the job analysis approach has the advantages of being objective, having clear definitions and a detailed measurement methodology. Yet, there are a number of sources of potential bias. First, estimates of mean years of required schooling in an occupation are constructed by aggregating various jobs within that occupation, ignoring the fact that there is likely to be a distribution of required education across those jobs. Some workers may, therefore, be mis-classified as overeducated as a result of within occupation variation in job specific schooling requirements (Halaby, 1994). Second, required schooling levels may vary for each occupation according to the abilities of job incumbents. As Rumberger (1987) and others have pointed out workers with higher levels of ability may require fewer educational qualifications to perform tasks effectively and vice versa. Education and ability are substitutes. Third, converting job scores, as in the DOT approach in the USA, into years of schooling is far from uncontentious, though in European studies which use educational dummies this sort of problem may be avoided. Fourth, levels of education ignore the type of education received and some workers who are mismatched may be mis-classified. As Halaby (1994) puts it, 'if plumbing requires a high school diploma then plumbers who work in any occupation requiring a high school diploma would be classified as matched even if plumbing skills are not used in the work'.

Most important however is that, fifth, such studies make the assumption that the educational requirements of occupations do not increase over time, whilst in practice both tasks and the required level of knowledge do alter over time (Smith, 1986). Since the objective method is very expensive and time-consuming, occupational classifications become available long after they have been measured, while furthermore, these classifications are typically used for a very long time-period, assuming no changes in the required level. However, as has been explained in section 2, the optimal level of skills for a certain occupation depends on market forces. Moreover, technological and organisational developments can change the requirements. Measurement of developments of underutilisation based on the objective method therefore includes both shifts in the optimal level, both due to changes in the relative scarcity and technological and organisational developments. The objective method therefore in practice picks up all three form of skills underutilisation distinguished in section 2 and is therefore not able to separate real underutilisation from alleged underutilisation of skills. It is therefore not surprising that the objective method tends to provide high levels of underutilisation of skills and also strong increases in these levels. Indeed a study by Van der Velden and Van Smoorenburg (1997), comparing the results of the objective and the subjective methods on one Dutch data set, finds that the job analysis method systematically overestimates the actual level of underutilisation.

Worker self assessment has been criticized because it is subjective and it is claimed that workers may not always have a clear insight into the actual level of education required. For example, workers may be inclined to overstate the requirements of their job in order to enhance the perceived status of their position. Stasz (1998) however found that employees report the actual skill requirements much more accurately than employers. Unlike in the job analysis method workers will be able to identify their own job rather than the occupation in general. Furthermore, workers may report changes in job requirements as soon as they show up. The 
method therefore might have clear advantages to measure pure developments in underutilisation, without incorporating biases due to changes in the optimal levels of skills within an occupation. If asked in the right wordings and correctly understood and reported by the worker the subjective measure therefore reflects genuine underutilisation of skills. There is however a severe risk that workers relate their situation to productivity standards form the past. This subjective measure would in that case adjust only gradually to new allocation equilibria and tend to a measure of intertemporal underutilisation of skills. Employees might furthermore simply state current hiring standards. Therefore tendencies of credentialism might be underestimated by the subjective method.

The empirical method has the advantage that it takes the theoretical foundation of the allocation theory as point of departure. When the labour market functions well to some extent, it might be expected that the majority of workers within a certain occupation has an appropriate educational background. Moreover, this approach will be very sensitive to labour market conditions and technological development, picking up changes in skill requirements very quick. Ideally, the method therefore reflects genuine underutilisation of skills. Measurement based on the labour force as a whole might be hampered by stickiness of existing working contracts. Again this might lead to some elements of intertemporal underutilisation to be included. Based on information about school leavers or other new matches on the labour market, the information might be very responsive to new allocation equilibria, however. Another advantage of this method is that it incorporates the possibility that a range of educational levels is appropriate for a given occupation, as illustrated in figure 2 . The empirical method will therefore do a good job to identify the appropriate level of education for a particular occupation and changes in this level. The demarcation line between adequate levels and levels which underutilisation occurs will however be arbitrarily to a large extent, since the method is based on criteria of frequency. If underutilisation occurs more than only incidentally the method might fail therefore, while furthermore it will not provide very precise measures of underutilisation.

It can be concluded that, although is seems to be clear that occupations that used to be occupied by lower skilled tend to be occupied by people with higher levels of education, it is not evident to what degree this really indicates underutilisation of the acquired skill level. Therefore, empirical information about such trends has to be treated with care.

\section{Shifting allocation of skilled labour: Causes and consequences}

To get a better understanding of the consequences of a policy that stimulates education among the low skilled, insight is required in the reasons why the employment in various occupational groups moves towards the higher skilled. In this section, therefore, different theories will be presented that explain this observed tendency of a movement within jobs towards the employment of higher educated. Furthermore it will be discussed in which way the labour market position of both the higher and lower skilled workers will be affected according to the different theoretical points of view. 
In section 2 the concept of the right level of education for a job has been analysed to provide a benchmark for the measurement of skill utilisation. It has been shown that even on a perfect labour market, where workers with different skill levels are allocated optimally, changes in the matching of workers with jobs might occur. Theories that explain the shift of higher educated towards jobs that used to be occupied by lower educated can therefore be distinguished in two groups: theories within the framework of the allocation theory and theories that claim that the actual allocation deviates from the optimality of allocation theory. In the first group three explanation for shifts in the employment structure are possible. First, they may be caused by changes in supply and demand per level of education or, second, by technological progress, expressed in a changing occupational productivity profile. Subsection 4.1 will focus on changes in supply and demand, while in subsection 4.2 the process of upgrading will be discussed. A third explanation that does not violate the essence of allocation theory can be found in the heterogeneity of workers with the same formal level. This issue will be discussed in subsection 4.3.

Although the allocation model seems to be able to explain both processes of bumping down and upgrading, there is some empirical evidence that contradicts this neo-classical theory. Economic literature provides theoretical arguments to explain these deviations from the optimal allocation of labour. These deviations have serious impact on the interpretation of the developments of the educational structure of the labour market. In subsection 4.4 the consequences of screening on the labour market is discussed. Subsection 4.5 continues with efficiency wage theories. In subsection 4.6 inflexible wages will be discussed.

The theoretical positions elaborated in these sections will be illustrated by some stylized facts from the U.K. and the Netherlands. Finally, in subsection 4.7 a typology of the various theories on the causes and consequences of the shift of the occupational domain of high skilled workers will be given. 


\subsection{Increasing supply or decreasing demand for higher educated}

In the allocation theory, described in section 2, the allocation of people with different levels of education is regulated by weighing the higher wages and increased productivity of the higher educated. The relative wages of the various levels of education reflect the scarcity of the different skill groups. Changes in supply for certain skill levels or demand for certain occupations will therefore influence the wages and the allocation of people over the occupations. If supply of the highest educational level goes up or demand for the jobs they are initially matched to goes down, the optimal match of these people will shift towards the lower level occupations. Since these people become relatively cheaper, employers with jobs that 'require' lower levels of education, might consider them as a serious alternative, as soon as their wages are low enough to be compensated by the higher productivity that will result from employing the higher educated. Also within their traditional occupational domain employment opportunities will increase since the costs per unit of production will go down. The increase of employment in their own occupational domain depends on the elasticity of demand on the relevant product market. Assuming however that this elasticity is very low, the wage of higher educated will decrease until there is enough labour demand within the lower qualified jobs for which they become attractive. Higher educated will therefore occupy part of the market of the jobs at one level below their own skill level. As a consequence demand for the workers with this lower skill level will fall. This effect is even amplified due to the higher productivity of the higher educated workers. The decrease in demand at the lower educational level will also push downward their wages. This will lead to a chain of shifts in the occupational domains, that can be typified as a process of bumping down.

If at all markets for educated labour the wage elasticity of demand is low, this wave will be transmitted to the lowest part of the labour market. The lower the wage elasticities of demand for the various levels of educated labour the more severe this tidal wave will ravage the lowest part of the market. This will either result in very low wages or a high level of unemployment for the low skilled workers. If the demand for unskilled labour is elastic, an increase in this unskilled work, with very low wages will result. If also the elasticity of demand for these unskilled jobs is inelastic or if a minimum wage hampers a wage adjustment for the unskilled jobs unemployment for the lower part of the labour market will result. Note that productivity does not go down because these workers have lower skills, but because the market value of these skills has gone down due to competition with higher educated workers. The above shows that even in allocation theory, based on straightforward neo classical assumptions, it is possible to explain a process of bumping down, with ultimately increased low paid jobs or unemployment for the lowest skill groups.

In case of an inelastic labour demand any exogenous decrease in demand, whether for high or for low skill jobs, will be transmitted to the lower part of the labour market. Empirical research has indeed shown that the unemployment rate of lower skilled workers is very sensitive to the business cycle. Teulings (1990) e.g. provides unemployment figures per skill level for the 
Netherlands. In table 2 his figures for 1979 and 1985 are presented. ${ }^{5}$ In 1979 total unemployment was relatively low, while in 1985 the economy was in a deep recession. The table shows that indeed the low skilled are hurt much more by this recession than people with higher levels of education. Teulings (1990, p. 200) states that these results show that the actual labour market dynamics deviate from the neo-classical theory: 'in a standard neo-classical model of the labour market there is no room for unemployment. Wage flexibility guarantees supply to be equal to demand in every market segment'. Apart from the discussion whether or not neo-classical theory leaves room for unemployment for people with a productivity above the minimum wage, the main difference between Teulings' 'standard neoclassical model' and the matching theory presented here is the endogeneity of the optimal match between the different levels of education and occupations. Teulings assumes that every level of education has its own occupational domain and thus supply and demand always have to equilibriate within this domain.

Table 2

Unemployment by level of education in the Netherlands in 1979 en 1985 according to Teulings (1990)

Unemployment 1979

$\%$ unemployment 1985

$\%$
Lower

Extended lower

Intermediate

Higher

Academic

Total

In persons x 1,000

$\left\{\begin{array}{cc}6 & 24 \\ 3.2 & 14 \\ & \\ 2.2 & 7.6 \\ & 6.3 \\ 3.2 & 6.2 \\ 167 & 12.7\end{array}\right.$

\subsection{Upgrading}

The alternative explanation that allocation theory offers for shifts towards lower level jobs in the employment structure of people with a certain level of education is the upgrading of the required skills in these jobs. Suppose that for one specific occupation the occupational productivity profile changes. Due to the introduction of new technologies or organisational changes productivity goes up. Spenner (1985, p. 126) describes this as 'the logic of industrialization [that] involves a division of labor that evolves along the lines of greater differentiation and efficiency. Technological change raises productivity, requiring a broader variety of skills and higher average skills from the work force'. As a consequence, within an occupation that faces an increase in complexity, the optimal level of education will go up, even if wages for this group will increase due to their increased scarcity. Murnane, Willett and Levy (1995) indeed find that the market value of cognitive skills has been rising. Empirically this will therefore lead to an increase of

5 A more recent overview of unemployment rates by level of education indicates that in various OECD countries the unemployment rate for low skilled workers is still much higher than the unemployment rate for high skilled workers (see Glyn and Salverda, 1998). 
employment of these higher educated people in jobs that were formerly occupied by lower educated. Since the new technologies imply by definition increased productivity, employment in number of persons might, furthermore, reduce within this occupation if demand on the product market is inelastic.

For the level of education concerned wages will increase. For the educational level that lost this occupational domain, ceterus paribus demand will fall, however. Assuming again a low elasticity of demand, their wages will go down. These lower wages might either make them competitive again with the higher educated that took over their jobs, or leads to a changed match of these skill levels with the jobs at a lower level of qualifications. Therefore also for these groups it will be observed that they occupy jobs that were previously occupied by lower qualified. While upgrading means an improvement of the labour market position for the skill levels which are directly affected by the changed occupational productivity profiles, for these lower educated workers, the effects are equivalent to the situation of decreasing demand as described in the previous subsection.

So upgrading will again induce a chain of shifts in the occupational domain accompanied with wage decreases for the lower educational levels. This might again finally push the low skilled workers into low wage jobs or unemployment. For the lower parts of the labour market, the consequences of upgrading versus excess supply of higher educated people are not completely opposite as is often suggested. Only if upgrading tendencies occur at all job levels, it seems fruitful to increase the education of the low skilled in reaction to these upgrading tendencies.

Table 3 provides information about the changes in required qualifications in Britain between 1986 and 1997 from Green et al. (2000). Except for level 3 all educational levels experienced an increase in demand. Interpreting these figures a measure of intertemporal skills utilisation, this would clearly indicate at upgrading tendencies in the UK for this period. Robinson (1997) estimates however that the shift of higher educated to lower occupations exceeds this increase in demand for higher skills, suggesting that the upgrading process is only a part of the explanation. According to table 3 the none qualified workers experienced a severe loss in demand between 1986 and 1997. The labour market position of these people could have been improved by additional education up to level 1 for approximately $25 \%$ of this group. This might have improved the labour market position of both those who received this additional education, but also of those who did not receive additional education, since the decreasing amount of jobs available for these low skilled workers would be available for a smaller group of workers. Assuming the elasticities of demand to be small, this would lead to an oversupply at level 1 , possibly inducing a bumping down process that again would hurt the people without qualification. In addition to the training for the none qualified, also additional education would be necessary to increase the skills of some of the workers with level 1,2 and 3. 


\begin{tabular}{lcc}
\hline & $\begin{array}{c}1986 \\
\%\end{array}$ & $\begin{array}{c}1997 \\
\%\end{array}$ \\
\hline High level & & \\
Level 3 & 20.2 & 23.8 \\
Level 2 & 15.3 & 13.3 \\
Level 1 & 18.5 & 21.4 \\
None & 7.7 & 8.9 \\
& 38.3 & 31.4 \\
\hline
\end{tabular}

\subsection{Heterogeneity of labour within an educational category}

Although allocation theory is able to explain the shifts in the occupational domain of skill groups adequately, both from a bumping down and an upgrading perspective, there is empirical evidence that its main assumptions do not hold. Evidence for this is provided by the observation that always part of the people with a certain educational qualification is found to be 'underutilised', whatever measure is used. Table 4 provides an example from Hartog and Jonker (1998), showing a subjective measure of underutilisation in the Netherlands to rise from 17 to $24 \%$ between 1974 and 1995. Besides this increase, the figures show that it is only a part of the workers at a certain a skill level that works below their educational level. Since, by neo-classical arguments, allocation theory predicts that people with the same skills will end up in the same position in the labour market, this finding contradicts the theory. In the allocation theory this can only occur when people are equally well of in both type of jobs. This turns out not to be true however. People working below their educational level systematically earn less than people adequately matched. A straightforward explanation for this, is the heterogeneity of workers with a certain level of education. If qualifications do not adequately reflect skills (see Steedman, 1998, OECD, 1998) than a certain qualification in fact represent a distribution of skills. Different levels of skills within this distribution might be allocated differently (see also Borghans and Smits, 1997).

Table 4

Underutilisation of education in the Netherlands based on workers self-assessment (Hartog and Jonker, 1998)

\begin{tabular}{lccc}
\hline & $\begin{array}{c}1974 \\
\%\end{array}$ & $\begin{array}{c}1982 \\
\%\end{array}$ & $\begin{array}{c}1995 \\
\%\end{array}$ \\
\hline Underutilised & 17 & 16 & 24 \\
Adequately matched & 53 & 62 & 63 \\
Overutilised & 30 & 22 & 12 \\
\hline
\end{tabular}

Underutilisation based on formal qualifications rather than actual measurement of skills does 
therefore not indicate at a non-optimal allocation. Heterogeneity might however go together with other explanations for the underutilisation of skills. Pryor and Schaffer (1999) show that in the US, the growth of low skill jobs has been larger than the growth of high skill jobs. As a consequence higher educated workers were forced to accept lower level jobs. Pryor and Schaffer show however that cognitive abilities vary among these higher educated. Their analysis based on the US National Adult Literacy Survey, shows that mainly those higher educated with lower cognitive abilities are employed in lower level jobs. This sheds other light on the interpretation of 'overeducation' of these workers.

\subsection{Screening}

An important issue in the economics of education is, however, the question whether the educational production process really delivers a constant output, even when the inflow increases. Opposed to the human capital theory (Becker, 1962) which treats education as a production process where skills are produced, screening theory (Spence, 1973) stresses the selectivity role of education. People differ in initial abilities, but employers lack information about these abilities. If it is assumed that children with more abilities can go through education more easily, education might become a screening device. It enables pupils to show their abilities to employers. In a so-called separating equilibrium, youngsters who stay long in school are associated with higher abilities and therefore earn higher wages. For the youngsters with less learning capacities it does however not pay off to continue longer in education. Although they would create the suggestion of having high abilities, their costs to complete the courses would be too high.

There is extensive evidence that screening-effects at least partially explain the income effects of education (Blaug, 1976, Weiss, 1995). Furthermore, the importance of screening might have become more important in the last decades ${ }^{6}$ (Lang, 1994, Borghans, 1998). As a consequence people with the same abilities, will stay in education longer and longer. This implies that the years of schooling as a scale to measure skills, does not only contain a measurement error, as in the case of heterogeneity, but also shifts in time. This process of increased screening might therefore very well explain the changing occupational domains of certain skill groups. The same qualification will after some time lead to lower level jobs and a lower wage. Actually, however, people with the same level of skills (correctly measured by their initial abilities) remain allocated in the same jobs at the same wage. Only the time they stay in education will increase. From a social point of view this implies overinvestments in education. However, this does not mean that (initial) abilities of workers are underutilised.

6 There is, however, also evidence that the return to 'educational signals' declines as additional work experience allows more direct estimates of production to be made by employers (Belman and Heywood (1997) and Battu, Belfield and Sloane, 1999). This has the implication that the proportion of workers who are 'properly matched' according to their formal qualifications may decline with age, which is referred to by Belman and Heywood (1997) as a 'sheepskin effect'. 


\subsection{Efficiency wages and search equilibria}

As mentioned before, it is an important stylized fact that workers with the same educational background, are not equally well off. This can be explained, on the one hand, by the heterogeneity of skills of the workers with a certain level of qualifications. An alternative explanation is that the labour market position someone reaches is random to some degree. People might have the same probabilities to reach a job at their level of education, but the ex post outcome might differ. The reason for this lottery might be that there is only a limited amount of adequate jobs available. Due to wage rigidity supply might structurally exceed demand. Excess supply then leads to unemployment or to employment at lower job levels.

It is generally regarded as a weakness of fixed wage theories that no explanation is offered for the reason why employers do not adjust wages if supply and demand are not in equilibrium. Much effort has been spend therefore to justify this crucial assumption. As a result of these foundations for wage-inflexibility, efficiency wage has been theory developed. Weiss (1990), provides an overview of these studies. Also the so-called equilibrium unemployment theories (Mortensen and Neumann, 1988 and Mortenson, 1990) typically depend on the assumption of an efficiency wage. An efficiency wage model introduces a relationship between productivity and the costs of losing ones job. Assuming that employers will not be perfectly able to monitor efforts, higher costs of losing a job will motivate employees to be productive in order to avoid the probability that an employer will discover their low level of effort and fires them. Employers might therefore pay more than the equilibrium wage to increase productivity. Since this argument holds for all employers, they will all pay the same wages. With full employment there would therefore be no costs of being fired. In basic models of efficiency wages this leads to unemployment, i.e. an equilibrium in which the average duration of unemployment times the reduction in income in that situation equals a level which optimally increases productivity of the workers with an appropriate job. However, without loss of argument this equilibrium might refer to a certain degree of underutilisation of labour instead of unemployment (Gautier, 2000).

Although efficiency wage models explain wages that deviate from equilibrium, wages are not fixed. This implies that although it might be observed that a substantial part of the workers with a certain skill level is employed below their educational level, there is no reason to expect that an increase in the supply of workers with this skill level will only lead to an increase of the number of workers who are employed below their skill level. The underutilisation of a fraction of the workers with this skill level only indicates the existence of a natural rate of underutilisation. Additional supply will also face this natural rate, but the fraction of workers whose skills are underutilised will remain unchanged.

\subsection{Fixed wages: the job competition model}

Until now it was assumed that wages reflect the marginal productivity of the people within each educational level. Although theory might explain shifts in the occupational domain of people and bumping down processes, in some sense their skills are utilised optimal. In literature it is often claimed however that the labour market does not clear in the way assumed by neo-classical 
theory. Absence of wage adjustments, i.e. fixed wages for each occupation, lead to job competition rather than wage competition. In this subsection we will discuss the consequences of such fixed wages per occupation.

In neo-classical allocation theory, a decrease in demand for higher educated workers might induce a bumping down process in which workers with a certain educational level take over part of the occupational domain of people with a lower level of education. This process might ultimately push the low skilled workers into badly paid work or unemployment. Assuming elasticities of demand to be close to zero for educated labour, additional education for these unskilled workers will not improve the situation on the labour market since the additional supply of workers with higher levels of education will further extend this bumping down process. An important characteristic of this model is, however, that higher educated labour will receive lower wages. Since in a neo-classical framework wages will be equal for all labour with the same personal characteristics, the wage will fall not only for those who have to accept a job that used to be in the domain of those who are lower educated, but also for the workers employed in their own 'traditional' occupational domain. Although productivity might be higher within the higher level jobs, wage competition among workers with equal characteristics for these scarce jobs 'at their own level' will push downward the wages until they are equal to the productivity in the lower skill jobs that have to be accepted by part of this group.

Although wage competition might therefore lead to a bumping down process, it will also diminish the returns to education. If students adequately anticipate these returns and their educational investments are based on the expected benefits of their investment, educational investments will diminish. This leads to an adjustment of labour supply to the demand shock. However, although many countries faced the shifts of higher educated workers to lower level jobs, a reduction of the average investments in education has never been observed.

These observations might suggest that the labour market is not regulated by wage competition but that job competition rules the market. Introduced by Thurow (1975) ${ }^{7}$ it is assumed in the job competition model that wages do not directly reflect the marginal productivity of the workers of a certain educational level. In contrast it is assumed that every type of job is characterized by a constant wage level. In more recent literature, these non-clearing wages are often explained by wage mark-ups due to monopolistic competition (Snower, 1983, Nishimura, 1989, Matsuyama, 1995 and Zwick, 2000). Knight (1979) illustrates that in that case, if the productivity of workers increases with their educational level, all employers will prefer to recruit the highest qualified people, even if the additional productivity compared with lower levels of educations is very low. These uniform preferences create what is called a queue of workers. The workers with the highest skill levels are in front of the queue which means that they have plenty of choice between all different jobs and will therefore choose the best paid occupations. However, for people with less qualifications the best-paid jobs will not be available. Therefore, similar to the queue of workers a job queue will arise. The outcome of this allocation process will be that the

7 Reder (1955) introduced the idea of occupational wage differentials two decades before Thurow. 
worker at the top of the queue will be matched with job number one, etc. If demand decreases in the best paid jobs everyone will shift some places downward in the queue. Reduced demand or excess supply for the high level jobs will therefore again result in a bumping down process that will either result in unemployment or in low paid jobs for the people at the end of the queue.

Although the wage competition model and the job competition model are often considered as opposite theories, both theories seem to be able to explain the process of bumping down. However, there are three important differences between both theories. In the first place a bumping down process is not an inevitable consequence of the neo-classical matching model. Only in combination with the assumption of low elasticities of demand a decrease in demand for the higher level jobs will be transmitted to the lower part of the labour market. In the job competition model the bumping down process will always take place. The reason for this is that with constant wages de facto no demand elasticity exists. Wage competition therefore seems to be able to predict a wider range of market mechanisms among which the extreme bumping down case is one.

The assumption of job dependent constant wages ${ }^{8}$, creates however two other differences between wage and job competition, which obstruct efficiency in the job competition model. First, the marginal benefits of educational investments in the job competition model do not equal the wage in the marginal job. If one more worker is schooled for the highest educational level, this will push one of the highest educated workers in the less favourable job. The marginal benefits are - in contrast with the wage competition model - larger than the wage in this marginal job, since every worker with this educational background only will face a probability to fall out the favourable occupational domain into these marginal jobs. Decreasing demand will therefore not provide a signal to reduce educational investments.

Second, also the allocation between workers and jobs might be obscured in the job competition model. Since wages are constant for each occupation, workers will not be allocated in the jobs where their productivity is optimal, but everyone will try to obtain those jobs that are best paid. If the jobs with the highest wages do not provide the highest comparative advantage for the highest skilled people talent will be wasted in less productive jobs. Murphy et. al. (1991) provide the example of highly rewarded lawyer jobs reducing national growth rates by preventing people to become engineer.

8 In contrast with occupation specific fixed wages, wages might also be fixed per level of education. Except for the influence of minimum wages on unemployment, not much attention is paid in literature to this situation, although many other institutional arrangements like wage bargaining agreements could explain the absence of wage flexibility within an educational level. Teulings (1990) provides a short description of the consequences. Changes in demand and supply will have no effect on the match between level of education and jobs anymore. As a consequence labour market problems will be faced for the workers with levels of education for which the wage is above equilibrium. Assuming a educationwage profile which is less steep than in equilibrium would lead to high levels of unemployment in the lower part of the labour market. Underutilisation would however not occur, while shocks in supply and demand will not be transmitted to the market segments for other levels of education. 
The implications of the job competition model regarding the efficiency of additional training for the lower part of the labour market to escape from low pay or unemployment are however more pessimistic than in the wage competition model. In the first place in the job competition model an increase in the supply of workers with higher levels of education will leave demand for those occupations totally unaffected. Improvements in the labour market position of those who receive additional schooling will be fully compensated by the deterioration of those who remain unskilled. Not only when decreased demand leads to a bumping down process it might be more efficient to reduce educational investments rather than to increase them, but also if demand increases there are good reasons to believe that the actual level of education exceeds the optimal level of education.

Crucial in the job competition model is the difference in wage between those who are lucky and find a job that matches their educational level, and those who have to accept a job below their skill level. The burden of excess supply is completely imposed upon the losers in the competitions for the favourable jobs. Borghans and Smits (1997) and Borghans, De Grip and Bruinshoofd (2000) investigated this implication. Table 5 shows that school leavers from the Dutch higher vocational education receive higher wages if they are employed in jobs for which higher educational levels are required. This confirms the findings of Hartog (1985) provided in table 1. This wage is found to react on the labour market situation however. The larger the percentage of school leavers that finds a job below the educational level within a specific labour market segment, the lower the average wage they receive. A deterioration of the labour market however affects the wages of those with a job that matches their educational level substantially more than the wages of the underutilised workers. This suggest that increased competition on the labour market also leads to wage competition within the traditional occupational domain. The smaller wage effects for those who work in a job below or above the level of higher vocational education can be explained by heterogeneity arguments. These arguments also predict a positive relationship between the average wage and the percentage workers below the educational level at the lowest level (lower vocational education).

Table 5

The average wage of school leavers from higher vocational education in the Netherlands in relation with the fraction of school leavers with a job below their educational level, from Borghans and Smits (1997) (t-values between brackets)

\begin{tabular}{lcccc}
\hline Required educ. level for job & \multicolumn{2}{l}{ constant } & \multicolumn{2}{l}{ \% below educational level } \\
\hline Lower & 14.76 & $(9.75)$ & 6.44 & $(1.09)$ \\
Intermediate & 18.84 & $(26.91)$ & -2.70 & $(0.98)$ \\
Higher vocational & 21.45 & $(26.34)$ & -5.25 & $(1.63)$ \\
More than higher vocational & 21.45 & $(24.16)$ & -2.34 & $(0.67)$ \\
Total group & 21.31 & $(30.66)$ & -6.13 & $(2.24)$ \\
& & & & \\
\hline
\end{tabular}

Van Ours and Ridder (1995) reject the job competition model because they estimated that in the 
job matching process higher educated do in case of a low number of vacancies within their own occupational domain not substantially reduce the matching probabilities of lower qualified people within other segments of the labour market. Higher unemployment rates among low skilled people are according to Van Ours and Ridder (1995) explained by higher quit rates. Although their findings provide very interesting insights in the functioning of the labour market, it is not clear however why the job competition model requires the reallocation induced by shifts in demand and supply to be realized through changing matching behaviour rather than changes in the quit ratio.

\subsection{A typology of the theories on the shifts in the allocation of labour}

Table 6 gives a typology of the theories that could explain a shift in the occupational domain of higher skilled workers towards lower job levels. As discussed in section 2 a shift in the occupational domain of higher skilled workers towards lower level jobs might very well be explained by allocation theory, which is purely based on the optimal allocation of people with different skills over the jobs. Moreover, both upgrading and increased supply of higher skilled workers might have similar effects. Higher skilled workers are employed in jobs in which lower educated workers used to be employed. However, in case of an upgrading of the skill requirements the labour market position of higher educated improves, while in case of an increase supply of higher skilled workers their position does not improve.

Especially when elasticities of demand in higher occupations are low, a shock in the labour market - also in case of upgrading - might lead to a bumping down process at the lower job levels, ultimately hurting the low skilled worker, eighter pushing them in badly paid jobs or into unemployment. However, in a labour market with higher elasticities for the better jobs could avoid these consequences at the lower part of the labour market.

There is however empirical evidence that allocation in reality deviates from the optimal allocation process described in section 2. Measurement of underutilisation of skills should be treated with great care however. If this evidence of deviations from optimal allocation is true, the main consequences concern the efficiency of both educational investment and allocation. For bumping down these deviations are not really relevant.

\section{Policy conclusions}

As mentioned in section 1 the aim of this paper was to discuss the effects of changes in supply and demand on the utilisation of skills, and the way in which shifts in the skill structure of the workers in various occupational groups affect the effectiveness of education and policy. For this purpose we developed a typology of the theories that explain the possible causes and consequences of the observed changes in the allocation of skilled labour and the related policy implications with respect to the (macro) efficiency of training policies for low skilled people. The overeducation and upgrading views provide the two extreme positions about what is going on. Analyses of the relationship between the acquisition of skills and labour market dynamics show 
that, depending on the situation, aspects of one view might go together with aspects of the other view.

It is interesting to notice that for the policy question whether or not the labour market developments make additional investments in schooling worthwhile, the opposite positions of the wage competition model and the job competition model are not crucial. The most crucial point is whether increased employment of higher educated in jobs on lower levels suggest the occurrence of a bumping down process initiated by excess supply for the higher educated or that it points at a process of upgrading. Bumping down - that can be the result in both the job competition model and the neo-classical matching model - suggest that additional investments in education are not very effective. Upgrading on the other hand requires an increase of educational investments. 'Upgrading versus bumping down' therefore seems to be the most fundamental opposition with respect to the macro efficiency of training policies for low skilled and low paid workers.

Two differences between the job competition and the wage competition model remain important, however. First, from the point of view of the wage competition model bumping down is only an extreme case. The model does not exclude that additional demand will absorb part of the extra supply at a certain level of education, which results from training policies. The effects of training therefore need not to be totally cancelled out by a bumping down process, but might also lead to new employment opportunities at higher wages, depending on the elasticity of demand at the higher job levels. In the job competition model elasticity of demand equals zero however, since wages will not react to changes in supply and demand.

Second, although both in a world of job competition and in a world of wage competition upgrading might occur, in the sense that jobs become more complex, the labour market will provide no signals for this in the job competition case. In the case of wage competition it might be very difficult to distinguish upgrading from bumping down, since both processes will lead to a shift in the employment structure of higher educated people to jobs that used to be occupied by lower educated. Upgrading does, however, manifest itself in a changing employment structure. In case of job competition nor the allocation of workers, neither their wages will be changed due to upgrading. The increased productivity of higher educated, which might make more educational investments fruitful will therefore remain unnoticed.

Finally, it is interesting to notice that not every form of training will be a useful instrument to cope with upgrading. It has been shown that upgrading in a specific group of occupations at a certain level of education might induce bumping at lower levels of education. Therefore training is only fruitful if it increases the supply at a level of education for which the upgrading process created new demand. Training that increases people's educational level, below the level where these upgrading tendencies occur, however, only further stimulates the process of bumping down. 
Table 6

Typology of theories that explain a shift in the occupational domain and their consequences

\begin{tabular}{|c|c|c|c|c|c|c|}
\hline \multirow[b]{2}{*}{ Consequences } & \multicolumn{3}{|c|}{ Within allocation theory } & \multicolumn{3}{|c|}{ Outside allocation theory } \\
\hline & upgrading & $\begin{array}{l}\text { increase in } \\
\text { supply }\end{array}$ & heterogeneity & screening & efficiency wages & $\begin{array}{l}\text { job } \\
\text { competition }\end{array}$ \\
\hline Overinvestment & no & no & no & yes & no & yes \\
\hline Wastage of skills & no & no & no & no & no & yes \\
\hline Lower wages & no, higher wages & yes & no & $\begin{array}{l}\text { yes, people end up } \\
\text { with the same wage } \\
\text { regardless their } \\
\text { qualifications }\end{array}$ & no & $\begin{array}{l}\text { yes, people } \\
\text { end up with } \\
\text { the same } \\
\text { wage } \\
\text { regardless } \\
\text { their } \\
\text { qualifications }\end{array}$ \\
\hline $\begin{array}{l}\text { Take away of jobs of } \\
\text { lower educated }\end{array}$ & $\begin{array}{l}\text { no, create job } \\
\text { opportunities for } \\
\text { lower educated }\end{array}$ & $\begin{array}{l}\text { yes, especially } \\
\text { when elasticity } \\
\text { of demand is } \\
\text { low }\end{array}$ & yes & $\begin{array}{l}\text { no, but forces people } \\
\text { to increase their } \\
\text { educational } \\
\text { investments to keep } \\
\text { the same job }\end{array}$ & yes & yes \\
\hline Bumping down process & $\begin{array}{l}\text { upgrading in high } \\
\text { level jobs might } \\
\text { result in bumping } \\
\text { down on the lower } \\
\text { end of the labour } \\
\text { market }\end{array}$ & $\begin{array}{l}\text { yes, especially } \\
\text { when elasticity } \\
\text { of demand is } \\
\text { low }\end{array}$ & no & no & no & yes \\
\hline
\end{tabular}




\section{References}

Alba Ramirez, A. (1993), Mismatch in the Spanish Labor Market: Overeducation? Journal of Human Resources 28(2): 259-278.

Alpin, C., J.R. Shackleton and S. Walsh (1997), Over and Under-Education in the UK Graduate Labour Market, Unpublished mimeo.

Battu, H., C.R. Belfield and P.J. Sloane (1999), Over-education Among Graduates: A Cohort View, Education Economics: 7-1: 21-38.

Becker, G.S. (1962), Investment in Human Capital: A Theoretical Analysis, Journal of Political Economy, 70: 9-49.

Belman, D. and J.S. Heywood (1997), Sheepskin Effects by Cohort: Implications of Job Matching in a Signalling Model, Oxford Economic Papers, 49(4): 623-637.

Blaug, M. (1976), The Empirical Status of Human Capital Theory: A Slightly Jaundiced Survey, Journal of Economic Literature: 827-855.

Borghans, L. (1993), Educational Choice and Labour Market Information. Dissertation, Maastricht.

Borghans, L., (1998), Human capital and screening with heterogenous learning activities, Paper presented at the EALE-Conference, Blankenberge.

Borghans, L., A. de Grip and W. Smits (1997), Future Developments in the Job level and Domain of Lowskilled Workers, Paper presented at the Conference on Problems of Low-wage. Employment of the European Low-wage. Employment Research Network (LOWER), Université Montesquieu, Bordeaux.

Borghans, L., A. de Grip, W. Smits and H. Zuurbier (1997), Het beroependomein van opleidingen, ROAR-1997/2, Maastricht.

Borghans, L., W. Smits (1997), Underutilisation and wages of HVE graduates, Paper presented at Applied Econometrics Association, Maastricht.

Borghans, L., A. de Grip and A. Bruinshoofd (2000), Low wages, Skills, and the Utilization of Skills , in:

L. Borghans and A. de Grip (Eds.), The Overeducated Worker? The Economics Skill Utilization. Cheltenham: Edward Elgar.

Bound, J. and G. Johnson (1992), Changes in the Structure of Wages in the 1980's: An Evaluation of Alternative Explanations, American Economic Review 75:371-392.

Bureau of Labour Statistics (1984), Occupational Outlook Handbook, Washington DC: US Department of Labor.

Davis, D.R. and T.A. Reeve (1997), Human Capital, Unemployment, and Relative Wages in a Global Economy, NBER Working Paper Series 6133, Cambridge (Mass.).

Department of Labor (1972), Handbook for Analysing Jobs, Department of Labor, Washington.

Dolton, P. and A. Vignoles (1997), The Incidence and Effects of Overeducation in the UK Graduate Labour market, Economics of Education Review 16.

European Commission (1996), Teaching and Learning. Towards the Learning Society, White Paper, Brussels. 
Freeman, R.B. (1976), The Overeducated American, Cambridge (Mass.).

Gautier, P.A. (2000), Do more high skilled workers occupy simple jobs during bad times?, in:

L. Borghans and A. de Grip (Eds.), The Overeducated Worker? The Economics of Skills Utilization. Cheltenham: Edward Elgar.

Glyn, A. and W. Salverda (1998), Employment Inequalities, Paper presented at the LOWER Conference

'Policies for Low-Wage Employment and Social Exclusion in Europe', University of Groningen.

Green, F., D. Ashton, B. Burchell, B. Davies and A. Felstead (2000), An analysis of changing work skills

in Britain, in: L. Borghans and A. de Grip (Eds.), The Overeducated Worker? The Economics of Skill Utilization. Cheltenham: Edward Elgar.

Grogger, E. and E. Eide (1995), Changes in College Skills and the Rise in the College Wage Premium. Journal of Human Resources 30(2): 280-310.

Halaby, C. (1994), Overeducation and Skill Mismatch, Sociology of Education, 67: 47-59.

Hartog, J. (1985), Earnings Functions. Testing for the Demand Side, Economics Letters 19: 281-285.

Hartog, J. (1997), On Returns to Education: Wandering Along the Hills of Our Land, Paper presented at Applied Econometrics Association, Maastricht.

Hartog, J. and H. Oosterbeek, (1988), Education, Allocation and Earnings in the Netherlands; Overschooling? Economics of Education Review, 7(2):185-194.

Hartog, J. and N. Jonker (1998), A Job to Match your Education: Does it matter? in: H. Heijke \& L. Borghans (Eds.), Towards a Transparent Labour Market for Educational Decisions, Ashgate, Aldershot: 99-118.

Harvey, L., S. Moon and V. Geal (1997), Graduates Work: Organisational Change and Students, Attributes University of Central England.

ILO (1996), Underemployment, ILO, Geneva.

Johnson, G. (1997), Changes in Earnings Inequality: The role of Demand Shifts, Journal of Economic Perspectives 11: 41-54.

Katz, L. and K. Murphy (1992), Changes in relative wages 1963-1987: Supply and demand factors, Quarterly Journal of Economics 107: 35-78.

Knight, J.B. (1979), Job Competition, Occupational Production Functions, and Filtering Down, Oxford Economic Papers 31: 187-204.

Kodde, P.A. (1986), Uncertainty and the Demand for Education, PhD thesis, Rotterdam.

Lam, A. (1996), Work organisation, skills development and utilisation of engineers, A British-Japanese comparison, R. Crompton, D. Gallie, K. Purcell (Eds.), Changing forms of Employment: London: 182203.

Leontief, W. (1953), Domestic Production and Foreign Trade: The American Position Re-examined, Proceedings of the American Philosophical Society.

Lang, K. (1994), Does the Human-Capital/Educational-Sorting Debate Matter for Development Policy? American Economic Review 71: 475-482.

Machin, S., A. Ryan and J. Van Reenen (1998), Technology and Changes in Skill Structure: Evidence 
From an International Part of Industries, CEP Discussion Paper No. 2971, London.

Mason, G. (1997), Back from the Dead Again? Production Supervisors in the United States, Britain and Germany, National Institute of Social and Economic Research Discussion Paper, No. 120.

Mason, G., B. van Ark and K. Wagner (1994), Productivity, Product Quality and Workforce Skills: Food Processing in Four European Countries, National Institute Economic Review: 62-83.

Matsuyama, K. (1995), Complementarities and Cumulative Processes in Models of Monopolistic Competition: Journal of Economic Literature, 33: 701-729, 1995.

Mortensen, D.T. (1990), Equilibrium Wage Distributions: A Synthesis, in J. Hartog, G. Ridder and J. Theeuwes, eds., Panel Data and Labor Market Studies, New York: North-Holland, 279-96.

Mortensen, D.T. and G.R. Neumann (1988), Estimating Structural Model of Unemployment and Job Duration in Dynamic Econometric Modeling, Proceedings of the Third International Symposium in: Economic Theory and Econometrics, Cambridge University Press.

Murnane, R., J. Willet and F. Levy (1995), The Growing Importance of Cognitive Skills in Wage Determination, NBER working paper 5076.

Murphy, K.M. (1991), The Allocation of Talent, Implications for Growth, Quarterly Journal of Economics: 106, 503-30.

Muysken, J. and B. ter Weel (2000), Does Overeducation Reduce Unemployment?, in: L. Borghans and A. de Grip (Eds.), The Overeducated Worker? The Economics of the Underutilization of skills Cheltenham: Edward Elgar.

Nishimura, K. (1989), Indexation and Monopolistic Competition in Labor Markets, European Economic Review, 33, pp. 1606-1623.

OECD (1996), Measuring what People Know, OECD, Paris.

OECD (1998), Human Capital Investment, An International Comparison, OECD, Paris.

Oosterbeek, H. and D. Webbink (1995), Enrolment in higher education in the Netherlands, De Economist 143(3): 367-380.

Porter, M. (1990), The Competitive Advantage of Nations, London: Macmillan.

Pryor, F. and D. Schaffer (1999), Who's Not Working and Why. Employment, Cognitive Skills, Wages, and the Changing U.S. Labor Market, Cambridge.

Reder, M. (1955), The Theory of Occupational Wage Differentials, American Economic Review 65: 833850.

Robinson, P. (1997), Underskilled or Over-Qualified? Qualifications, Occupations and Earnings in the British labour Market, paper presented at the LoWER conference, London.

Roy, A.D. (1950), The Distribution of Earnings and of Individual Output, Economic Journal 60: 489-501.

Roy, A.D. (1951), Some Thoughts on the Distribution of Earnings, Oxford Economic Papers 3: 135-46.

Rumberger, R.W. (1987), The Impact of Surplus Schooling on Productivity and Earnings, Journal of Human Resources 22(I): 24-50.

Rumberger, R.W. (1981), Overeducation in the US Labor Market, New York: Praeger.

Santos, M., M. Mendes Oliveria and B.F. Kiker (1996), Overeducation and Undereducation: evidence 
for Portugal, Paper presented at the EALE Conference, Crete.

Shockey, J.W. (1989), Overeducation an Earnings: A Structural Approach to Differential Attainment in the US Labor Force (1970-82), American Sociological Review, 54: 856-864.

Sicherman, N. (1991), Overeducation in the Labor Market, Journal of Labor Economics, 9(2): 101-122.

Sloane, P., H. Battu and P. Seaman (1996), Overeducation and the Formal Education/Experience and Training Trade-Off, Applied Economics Letters, 3: 511-515.

Smith, H. (1986), Overeducation and Underemployment: An Agnostic Review, Sociology of Education, 59: 85-99.

Snower, D. (1983), Imperfect Competition, Underemployment and Crowding Out: Oxford Economic Papers, 35, suppl., pp. 245-270, 1983.

Spence, O.F. (1973), Job Market Signalling, Quarterly Journal of Economics 87: 355-374.

Spenner, K.L. (1985), The Upgrading and Downgrading of Occupations: Issues, Evidence and Implications for Education, Review of Educational Research 55: 125-154.

Stasz, (1998), Generic Skills at Work: Implications for Occupationally-Oriented Education, in: W.J. Nijhof and J.N. Streumer (Eds.), Key Qualifications in Work and Education, 187-206.

Steedman, H. (1998), Measuring the Quality of Educational Outputs: Some Unresolved Problems, forthcoming in: R. Alexander, P. Broadfoot, D. Philips (eds.), Learning from Comparing: New Directions in Comparative Education Research, Triangle Books.

Teulings, C. (1990), Conjunctuur en Kwalificatie, Amsterdam: SEO, Universiteit van Amsterdam.

Teulings, C. (1995), The Wage Distribution in a Model of the Assignment of Skills to Jobs, University of Amsterdam, Journal of Political Economy, 103: 280-315.

Thurow, L. (1975), Generating Inequality, New York.

Tinbergen, J. (1956), On the Theory of Income Distribution, Weftwirtschaftliches Archiv 77: 156-73.

Tinbergen, J. (1975), Income Distribution: Analysis and Policies, Amsterdam: North-Holland.

Topel, R. (1997), Factor Proportions and Relative Wages: The Supply-Side Determinants of Wage Inequality, Journal of Economic Perspectives 11: 55-74.

Van der Velden, R.K.W. and M.S.M. van Smoorenburg (1997), The Measurement of Overeducation and Under-education: Self Report vs Job analyst Method, Paper presented at the 9th Annual EALE Conference, Aarhus.

Van Ours, J.C. and G. Ridder (1995), Job Matching and Job Competition: Are Lower Educated Workers at the Back of Job Queues?, European Economic Review 55: 125-154.

Verdugo, R.R. and N.T. Verdugo (1989), The Impact of Surplus Schooling on Earnings: Some Additional Findings, Journal of Human Resources, 24(4): 629-643.

Weiss, A. (1990), Efficiency Wages, Models of Unemployment, Layoffs, and Wage Dispersion, Princeton University Press, Princeton, New Jersey.

Weiss, A., (1995), Human Capital vs. Signalling Explanations of Wages, Journal of Economic Perspectives 9: 133-154.

Wood, A. (1994), North-South Trade, employment and Inequality. Changing Fortunes in a Skill Driven 
World, Oxford.

Zwick, Th. (2000), Overqualification Makes Low-Wage Employment Attractive, The Economics of upgrading and bumping down, in: L. Borghans and A. de Grip (Eds.), The Overeducated Worker? The Economics of the Underutilization of skills Cheltenham: Edward Elgar. 